\title{
A Solar Photovoltaic Performance and Financial Modeling Solution for Grid-Connected Homes in Zambia
}

\author{
Katundu Imasiku \\ Southern African Science Service Centre for Climate Change and Adaptive Land Management, 28 Robert Mugabe Avenue, \\ Cnr Robert Mugabe and Newton Street, Windhoek, Namibia \\ Correspondence should be addressed to Katundu Imasiku; katunduimasiku@gmail.com
}

Received 4 September 2020; Revised 27 May 2021; Accepted 24 July 2021; Published 13 August 2021

Academic Editor: Umapada Pal

Copyright ( 2021 Katundu Imasiku. This is an open access article distributed under the Creative Commons Attribution License, which permits unrestricted use, distribution, and reproduction in any medium, provided the original work is properly cited.

\begin{abstract}
Zambia is today $90 \%$ hydropower dependent, but this may change because Zambia and the World at large are today facing a changing climate that affects the ecosystem, rain patterns, and spurs drought which reduces the production of hydropower. The current power deficit experienced in Zambia points to a need to deploy a renewable energy generation-mix strategy. This study conducts a solar photovoltaic performance and financial analysis for grid-connected homes in Zambia to investigate the role of solar energy as an enabler for energy security in Zambia using the National Renewable Energy Laboratory (NREL) System Advisor Model (SAM) simulation method. It further reviews the available solar irradiance, modeling a detailed grid-connected photovoltaic system using locally available products for a single owner in a power purchase agreement (PPA) with the Zambia Electricity Company Limited (ZESCO). This model would alleviate the current power load shedding experienced by the residential sector, of up to 22 hours of no electricity out of 24 hours in a day. Alongside the technical performance model and an unfavorable business climate in Zambia, a financial model is also developed to help assess project feasibility and financial viability. A $1 \mathrm{~kW}$ solar PV system was modeled at an installation cost of US $\$ 1.27$ per watt on a short-term basis of 5 years and found that the project is feasible with a $28.52 \%$ IRR achieved in 3 years and a 69\% performance ratio and a debt service coverage ratio (DSCR) of 5.12 by the end of the project life, thereby indicating capability to turn around Zambia's energy poverty to meet the UN SDG 7.
\end{abstract}

\section{Introduction}

Zambia is a hydrodependent country but is currently facing a massive power load shedding that is a result of drought during the 2018/2019 rainy season. This has forced ZESCO to load-shed off most of the customers for up to 22 hours, out to 24 hours in a day [1].

In the $21^{\text {st }}$ century, the use of renewable resources like wind and solar has been propagated by the spectre of climate change and its associated impact like drought. However, this ramp in the use of renewable resources like solar has been further exacerbated by the decline of the cost of photovoltaic modules and associated components like inverters and batteries which have made the installation cost and levelized cost of photovoltaic systems relatively low in many countries. This has further led to reduced electricity bills on the customer end especially with of feed-in tariff strategy $[2,3]$. Further, advances in the electronics industries have led to more efficient and reliable integration of solar systems into electrical power grids [4-6]. The concepts of microgrid have also led to developing distributed generation (DG) systems where a self-generation unit can be connected to the national utility grid $[3,6,7]$.

Photovoltaic electric power generation is environmentally and economically sustainable and feasible and while requiring a generally low maintenance cost to operate. PV systems are regularly promoted and explained as module DC power rating and are expressed as \$'s/watt. Notwithstanding, the value of a grid-tied solar system is a function of the generated energy, expressed in kilo-watt-hour (kWh) $[8,9]$. The photovoltaic systems can be operated as either stand-alone or in grid-connected mode. A grid-connected model is proposed for this solution to enhance the current power generation deficit in the Zambia Electricity Company Limited (ZESCO). This system is ideal because the grid power supply is not readily available and worse of costly. A 
hybrid system of solar-hydroelectric power will allow the use of batteries as a backup especially when the utility power has failed, or to meet the demand control or for ZESCO to offer Time of Use (TOU) rates.

The performance of grid-connected photovoltaic systems relies on photocell technology, inverters, system cost, and system configuration than the weather conditions like global irradiance, the ambient temperature, or even losses caused by soiling. This is inferred from previous studies by SolanoPeralta et al. [2], who evaluated the performance of a solar photovoltaic system in comparison to the performance of different simulated photovoltaic systems. Edalati et al. [10] looked at the experimental performance of two regular monosilicon and polysilicon ( $\mathrm{m}-\mathrm{Si}$ and $\mathrm{p}$-Si) photovoltaic module technologies. Other previous studies on the performance parameters of installed photovoltaic systems in various locations and with distinct climatic conditions [11-14] alongside research work on solar thermal, solar photovoltaic, solar radiation, and financial analysis of a grid-connected photovoltaic system modeling have been carried out by various researches [15-17]. The Zambian solar PV system was modeled using the System Advisor Model (SAM). Using the current weather file database for Zambia from http:// Climate.OneBuilding.Org [18] and the SAM, the simulation benchmark helped predict the most favorable scenario for providing a solution for solar photovoltaic performance and financial model for grid-connected homes in Zambia. The SAM is a renewable energy performance modeling and financial modeling tool which is used to predict and cost energy estimates for a grid-connected photovoltaic (PV) project and operation costs and system parameters in Zambia with a configuration of a purchase agreement (PPA) between house owners and ZESCO and homeowners to sell the excess power to the ZESCO grid.

Using SAM software for renewable energy systems, a two-bedroomed house was selected for load sizing because this is the type of accommodation affordable to the majority and middle-income earners in Zambia to model a suitable PV system. The photovoltaic-based performance system comprising a small residential rooftop PV module, an inverter, and a storage battery connected on the direct current (DC) side was found to be suitable $[19,20]$.

The financial model involves determining the internal rate of return (IRR) alongside other important annual cash flow metrics like the debt service coverage ratio (DSCR), the net present value (NPV), and levelized cost of electricity (LCOE) for the power purchase agreement (PPA) between the Zambian electrical utility-ZESCO [21]. As opposed to servicing this loan in about 15 years to 25 years, the lending institutions in Zambia have established unfavorable borrowing terms which demand collateral of about $67 \%$ the value of the amount needed and limited to a period of 2 years- 5 years. Further, business loans in Zambia also attract interest rates of $55 \%-75 \%$ annually and are subject to a viability assessment report by bank officials/loan officers, which includes a reputable financial history and profitable financial track record. In addition, most banks in Zambia demand that the first amortization installment commences a month or two after disbursement $[22,23]$. Solar financing is thus viewed as being very risky in Zambia due to because of the poor payback rates and generally a poor business climate [24]. Ideally, the project is expected to be installed over 6 months, and this waiting period by the financial institutions or banks before they can get their first pay-back installment needs some insurance, assurance, or even good financial negotiations. The situation is further exacerbated by high inflation rates in Zambia [25]. This makes it very difficult for citizens to borrow, hence the need to involve the Zambian government and ZESCO in a PPA to build a good case for borrowing.

This research study is aimed at finding a short-term (5 years) renewable energy solution by developing a solar photovoltaic performance model and financial model solution for grid-connected homes in Zambia to provide electricity to homes and business houses in Zambia although the business climate does not allow long-term debt or borrowing for 15-20 years. The study mainly assesses the performance parameters like photovoltaic system cost, yield, reference yield, and system performance ratio (PR), quality factor, turnover rate, financial climate in Zambia, and the irradiance and system losses to evaluate overall system performance compared to hydropower and diesel backup power cost [26].

\section{Methodology}

A fivefold method was adopted of, first, sizing a grid-connected two bedroomed home, second, designing a performance model, third, designing a financial model and designing the power purchase agreement (PPA) terms, and finally, integrating the performance, financial, and PPA models into a comprehensive case and drawing some conclusions and recommendations concerning sustainable solar photovoltaic performance and financial modeling solution for grid-connected homes in Zambia. Figure 1 shows the research method steps.

2.1. Solar Load Sizing. Previous studies by Shebo Nalishebo established that an average monthly household family size for middle-income earners in Zambia ranges between 5766 and 26231 (Zambian Kwacha). Out of a total of 71438 households, about $60 \%$ which translate to 41824 households are middle-class worker occupations. From this study, it is inferred that a two-bedroomed house is what most middleincome earners occupy [20].

To size a solar photovoltaic system for a two-bedroomed house, we estimate the total consumed power in Table 1.

To find the total energy consumption, we multiply the total power consumption in Table 1 by the set direct current (DC) to alternating current (AC) conversion factor. The role of this conversion ratio is to find an optimal balance of the system performance and the cost. While 1.2 is the rule of thumb ratio that is adopted by most designers [27], the inverter (Jiangyin HR-240P-AC/BbP) and solar module (China Sunergy-Nanjing CSUN285-60M) selected in the SAM has a DC power output of $285.3 \mathrm{Wdc}$ while the inverter has an AC power output of $240 \mathrm{Wac}$ (285.3/240), thereby giving a ratio of 1.19; therefore, the total power requirement for a two-bedroomed house is as follows. 


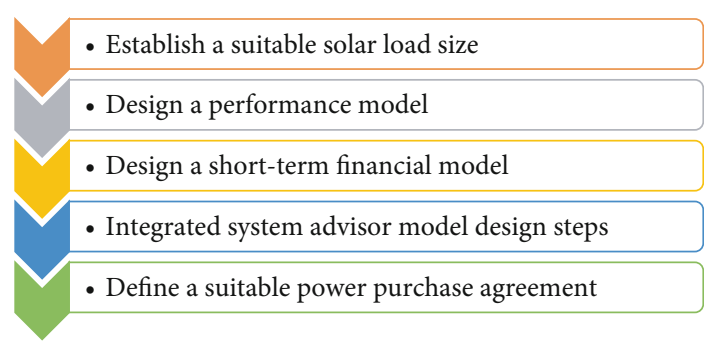

FIgURe 1: PV system modeling methodology.

The mathematical expression for calculating the DC to $\mathrm{AC}$ ratio is given by

$$
\mathrm{Bj}^{\prime}=\mathrm{Bj} \times \frac{\mathrm{DC}}{\mathrm{AC}} \text { ratio, }
$$

where $\mathrm{Bj}^{\prime}$ is the total required energy and $\mathrm{Bj}$ is the required energy.

Applying equation (1), and using the value of $\mathrm{Bj}$ in Table 1 , as being equal to $801 \mathrm{wh} /$ day,

$\mathrm{Bj}^{\prime}=1.19 \times 801=952.19$ watt-hour/day (or amp-hour/day) .

Therefore, the researcher aimed to design a one kilowatt $(1 \mathrm{~kW})$ PV system. This is the target size that will be simulated in the SAM.

2.2. Designing a Performance Model. The performance model in SAM involves the following inputs for the PV system design [21]:

(i) Choosing a Location. For this research, Zambia's capital city, Lusaka was selected with location details, latitude of $15.33^{\circ} \mathrm{E}$, longitude of $28.45^{\circ} \mathrm{E}$, and elevation of $1151.8 \mathrm{~m}$

(ii) PV Module Selection. Since Zambia is flooded with low efficient Chinese PV modules [19], the selected module selected was the China Sunergy-Nanjing CSUN285-60M mono-c-Si with a nominal efficiency of $17.6875 \%$

(iii) Inverter Selection. Like the PV module, a Chinese inverter which is not very efficient was selected comparable to the products available on the Zambian market. The selected module in SAM is the Jiangyin Hareon Power: HR-260P-AC/BbP-240V [19]

(iv) System Design. Since this is a simple power supply system for the supply of power to a twobedroomed house, the size of the system comprised one inverter, one module with $1.6 \mathrm{~m}^{2}$, one string with a string, and a module with a fixed tracking and orientation. For Lusaka, Zambia the azimuth was calculated to be $50.25^{\circ}$ while the tilt was calculated to be $62.72^{\circ}$ [28]. The electrical sizing of the selected module in the SAM database has $37 \mathrm{Vdc}$ and a maximum power point tracking (MPPT) ranging between $25 \mathrm{Vdc}$ and $37 \mathrm{Vdc}$

(v) Estimate Shading Levels. These are determined in the SAM by default

(vi) Determine Losses. These cannot be predetermined before the analysis of the designed system

2.3. Designing a Financial Model. The financial model calculates the PV project's cash flow over a three-year period, capturing the value of the generated electricity annually and over the three years, installation costs, operation and maintenance cost, taxes, and most importantly the fact that the assumption that the financial source for the project will be a debt [21]. The model is focused on establishing the internal rate of return (IRR) alongside other important annual cash flow metrics like the debt service coverage ratio (DSCR), the net present value (NPV), and the levelized cost of electricity (LCOE) for the power purchase agreement (PPA) between ZESCO and single owners (households) and, most importantly, finding the capacity factor and performance factor. This approach was chosen because it considers the high inflation rate in Zambia which is currently around $10.7 \%$ and a government value-added (VAT) tax of $16 \%$. Since this is a new project, depreciation is not accounted for. The only piece of equipment which is replaced annually on account of depreciation is the energy storage system-battery. The current cost of hydropower electricity in Zambia is 6.39 US\$ $\mathrm{c} / \mathrm{kWh}$ [29]. The following mathematical expressions for the key financial flow metrics are given as follows:

Internal rate of return (IRR) and net present value (NPV)

$$
\mathrm{NPV}=\sum_{n=0}^{N} \frac{C_{n}}{(1+\mathrm{IRR})}=0
$$

where $C_{n}$ is the after-tax cash flow.

Levelized cost of electricity (LCOE)

$$
\mathrm{LCOE}=\frac{\mathrm{FCR} \times \mathrm{TCC}+\mathrm{FOC}}{\mathrm{AEP}}+\mathrm{VOC},
$$

where FOC is the fixed annual operating cost (US\$), TCC is the capital cost (US\$), VOC is the variable operating cost $(\$ / k W h), F C R$ is the fixed charge rate, and AEP is the electricity produced annually $(\mathrm{kWh})$.

Since there is no known capital investment in the project, the researcher assumes that this project will be financed as $100 \%$ debt. The researcher also assumed that an equal payment or standard amortization rate over 5 years and a degradation rate of $1 \%$ while the nominal discount rate of $10.7 \%$ was predetermined by Zambia's high inflation rate which is currently $10.7 \%$ [25]. Other assumptions for the simulation are that there is no cost attached to acquiring finance and a nominal 10\% annual interest rate on all accounts, including debt, working capital, and replacement reserves. The final assumption concerning the cost of the PV installations is that ZESCO already has technicians who have handled major power installation and these can be 
TABle 1: Two-bedroomed nominal power peak-hour energy consumption for middle-income earner in Zambia.

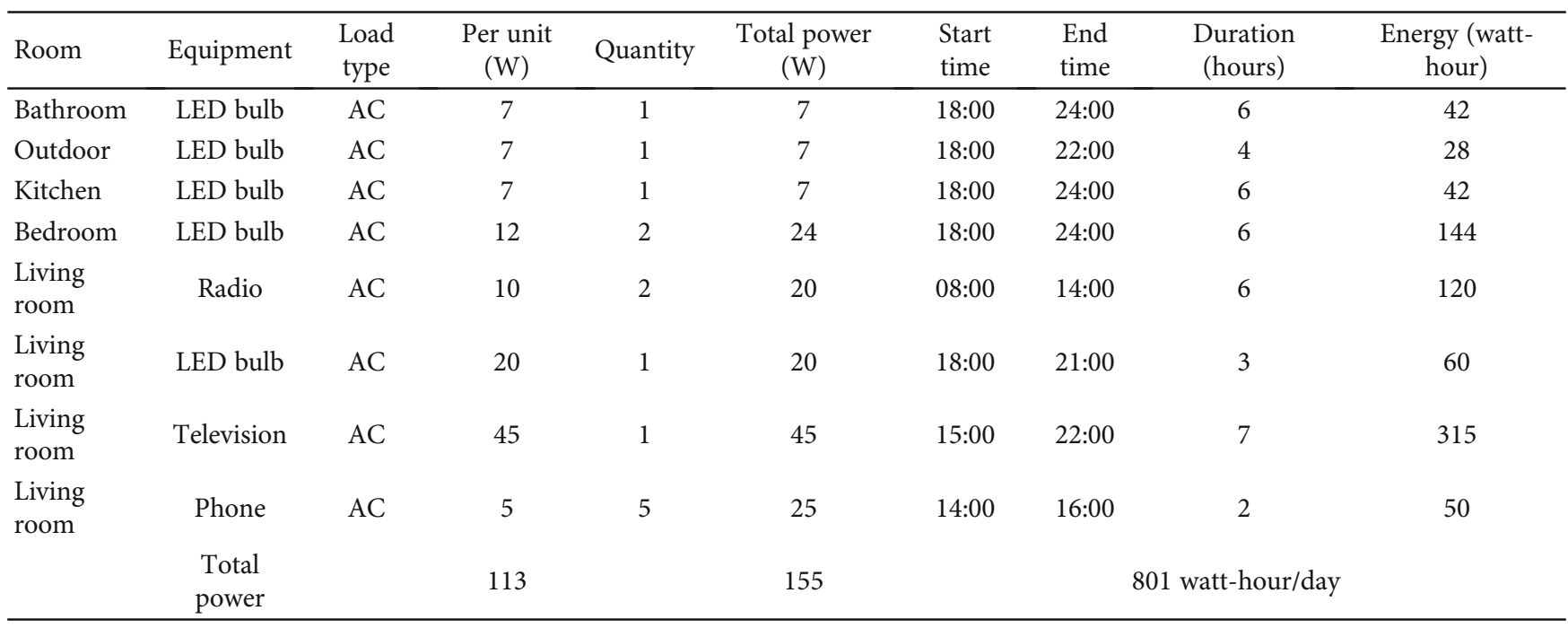

Note: this time of departure (TOD) in the table is meant for load sizing, but the TOD applied in SAM is evenly distributed from 23:00 am to 23:00 pm per day.

easily trained to carry out these installations during the first three months of no operation. One critical incentive for the proposed PPA is that the government should consider waiving the $16 \%$ value-added tax (VAT) to encourage the borrowers. These assumptions are part of the basis for a PPA between households, the government of Zambia, ZESCO, and financial institutions that may be willing to fund solar projects.

2.4. System Advisor Model Modeling Steps. The following five critical steps were followed to determine a suitable gridconnected PV system that can provide $1 \mathrm{~kW}$ of power per day using the SAM:

Step 1. Set up the PV system design by selecting a direct current inverter side configuration and adjust the number of modules and cells in strings to obtain $\mathrm{Bj}^{\prime}$ energy in the SAM. Further, a fixed PV orientation was also selected, and tilt and azimuth angles were also computed and entered.

Step 2. Select a solar panel that is comparable to those available in Zambia [19]. The selected PV module is the China Sunergy-Nanjing CSUN285-60M with the following IV- characteristic curve; nominal efficiency is $17.6875 \%$, maximum power (Pmp) is $285.3 \mathrm{Wdc}$, max power voltage (Vmp) is $31.7 \mathrm{Vdc}$, maximum power current (Imp) is $9 \mathrm{Adc}$, open-circuit voltage (Voc) is $38.8 \mathrm{Vdc}$, short-circuit current (Isc) is $9.3 \mathrm{Adc}$, and module irradiance is $1000 \mathrm{~W} / \mathrm{m}^{2}$ with cell temp of $25^{\circ} \mathrm{C}$.

Step 3. Select the inverter that is comparable to those available in Zambia [19]. The selected inverter is the Jiangyin Hareon Power: HR-260P-AC/BbP-240V with the following efficiency curve and characteristic; maximum AC power is $240 \mathrm{Wac}$, maximum DC power is $252.486 \mathrm{Wdc}$, power consumption under operation is $1.67325 \mathrm{Wdc}$, power consumption at night is $0.072 \mathrm{Wac}$, nominal AC voltage is $240 \mathrm{Vac}$, maximum DC voltage is $37 \mathrm{Vdc}$, maximum current is $7.89017 \mathrm{Adc}$, minimum MPPT DC voltage is $25 \mathrm{Vdc}$, nominal DC voltage is $32 \mathrm{Vdc}$, and the maximum MPPT $\mathrm{DC}$ voltage is $37 \mathrm{Vdc}$.
Step 4. Select a storage battery type in SAM. The lead acid: VRLA AGM battery was selected because these are readily available in Zambia and affordable. The nominal power bank capacity is $1.2 \mathrm{kWh}$ (DC) with a nominal bank voltage of $48 \mathrm{~V}$ (DC).

Step 5. PV system cost. The PV module was paged at US\$200 per module while the inverter was paged at US\$180. The battery pack was paged at US\$144. Further, a fixed annual operation cost of US\$144 was allocated mainly for annual battery replacement.

2.5. Power Purchase Agreement (PPA). Some critical assumptions and recommendations for a possible PPA between the single household owners, the Zambia power utility ZESCO, and the government of Zambia are as follows:

(i) That government should assist single homeowners to secure the PV system debt/loan from financial institutions at a negotiated $10 \%$ annual interest as opposed to the current annual interest rates of about $28 \%$ for personal loans and between 55\% and $78 \%$ for business loans $[22,23]$

(ii) That ZESCO will provide the technical staff to carry out the installation in a manner that will not destabilize the ZESCO grid

(iii) The government to provide a tax incentive on the loan by subsidizing or entirely removing the government earnings of $16 \%$ value-added tax on the loan and insure this short-term debt at a marginal $5 \%$ rate

(iv) Like most solar PV leaders, with high solar energy production like the USA and Germany, Zambia also needs to introduce an investment tax credit (ITC) of $30 \%$ as an incentive for solar projects to reduce the PV system depreciation costs and encourage solar PV investment and growth in Zambia [30] 
(v) The payback period will be three years while the total project life period of the analysis is 5 years. The duration of solar PV financing is much lower (5 years) instead of long-term financial options of 15 years to 25 years because the financial climate in Zambia is not conducive. Most financial institutions in Zambia are not comfortable offering long-term loans to their clients especially on development projects like solar energy development because solar PV loans typically should be serviced in about 15 years to 20 years. Further, this is made worse by the fact that Zambia has a very high annual inflation rate exceeding $10 \%$

(vi) That ZESCO should consider upgrading the system for higher capacity for more excess power generation

(vii) That the single households will only own the supplied PV system after three years of completing repaying the debt. During the 3 years, ZESCO should maintain the system after which any minor maintenance will be done by the owner or in collaboration with ZESCO at a nominal fee

(viii) The LCOE for diesel backup power systems is much higher than that of the solar power systems. This will mean that ZESCO will benefit from solar energy generation because it is cheap and easy to maintain

(ix) To ensure power and grid stability, the ZESCO utility might need extra equipment (LC and RLC harmonic filters) to filter the PV AC hydropower fed into the grid so that harmonics are not introduced into the national grid

\section{Results and Discussion}

The electricity crisis in Zambia presents an opportunity for Zambia to transition from being a hydrodependent nation to a solar-dependent nation and supply affordable and cleaner energy for the poor majority in Zambia [31].

Designing and incorporating these systems into the ZESCO grid are a major possible research direction. This will diversify the power system beyond solar electricity because solar systems have lower operations and maintenance costs and will help Zambia provide affordable clean energy for all, thereby meeting the UN SDG 7 and reducing the overdependence on hydropower which is subject to good rain patterns [32].

This research found that Zambia has a large potential to develop and fully exploit solar energy resources because it has a higher global horizontal irradiance (GHI). The total direct normal irradiance (DNI) per day is up to $6.6 \mathrm{kWh} / \mathrm{km}^{2}$ and the annual sum exceeding $2410 \mathrm{kWh} / \mathrm{km}^{2}$ especially in Luapula, Southern and Western provinces [33]. The researcher allowed SAM to adopt a default setting which utilizes the beam or DNI and the diffuse horizontal irradiance (DHI) from the weather files from http://Climate .OneBuilding.Org [18], to calculate the incident irradiance.
The DNI is more relevant for concentrator PV systems (CPV) and thermal solar power plants (CSP) [34]. The GHI and DHI are relevant to the performance characteristics of the PV technology. Further, the plane of array (POA) irradiance is the total solar radiation that reaches the photovoltaic array surface per unit area [21]. Figure 2 shows the simulated irradiance components for Zambia.

Figure 2 shows that the calculated GHI reduces as winter approaches and increases in summer and further reduces during the rainy season from November to February. In this research, a fixed mounting structure at an optimal angle was selected to lower the cost of the PV system modeled. With this huge irradiance potential, Zambia should take advantage of this renewable resource and turn each household into a generating station. Zambia enjoys an average GHI solar irradiance of $1450 \mathrm{~W} / \mathrm{m}^{2}$, with a maximum of about $1100 \mathrm{~W} / \mathrm{m}^{2}$ and the lowest months recording about $700 \mathrm{~W} / \mathrm{m}^{2}$. While countries like Germany with monthly irradiance of only $5 \mathrm{~W} / \mathrm{m}^{2}$, and about $15 \mathrm{~W} / \mathrm{m}^{2}$ of global irradiance have about $50 \mathrm{GW}$ of installed PVs and yet only yields an output of $3 \mathrm{GW}$ annually $[35,36]$, the current solar installed capacity in Zambia is only $0.04 \%$ out of the total $2892.94 \mathrm{MW}$ produced by hydrogeneration [15], [37]. This shows that Zambia underutilizes its solar resource.

Figure 3 generally shows that the irradiance in Zambia is adequate to produce DC and AC energy throughout the year for the modeled PV system. The modeled PV system is a $1 \mathrm{~kW} /$ day which translates to produce about $30 \mathrm{~kW} / \mathrm{month}$. The designed PV system has met the targeted $30 \mathrm{~kW} /$ month in all the months but clearly shows that some months like January, February, November, and December have lower energy production, mainly due to this period being in the rainy season. The efficiencies of solar panels reduce by about $10 \%$ to $25 \%$ of their optimal capacity [38]. Although May, June, and July are the winter months in Zambia, the production is even higher than in the rainy season. This is because solar PV systems depend on light to operate [39]. The produced AC and DC energy is far almost 50\% higher than the targeted $30 \mathrm{~kW} /$ month in all months. The total annual load demand is $300 \mathrm{~kW}$ while the modeled PV system is capable of yielding $613 \mathrm{~kW} /$ year. Further, with a well-designed PV system that is not cost-conscious and with the best available PV components installed, especially efficient PV modules, inverters, and energy storage batteries, more energy can be harvested in Zambia because it has abundant solar irradiance with a daily sum of global horizontal irradiance (GHI) of up to $6.6 \mathrm{kWh} / \mathrm{km}^{2}$ and annual sum exceeding $2410 \mathrm{kWh} / \mathrm{km}^{2}$ especially in Western, Southern, and Luapula provinces of Zambia [33].

Figure 4(a) shows that out of all the PV system losses, the highest contributor to the losses is the shading caused by the plane of array losses on the front side of the module, the plane of array losses of the font side soiling loss, and the plane of array losses attributed to the internal PV module modeling losses. Further, Figure 4(b) shows how much energy is lost from the available $4983 \mathrm{kWh}$ at the nominal plane of the array through DC and AC losses to about $613 \mathrm{kWh}$ which translates into a marginal annual energy output of only $12.3 \%$. 


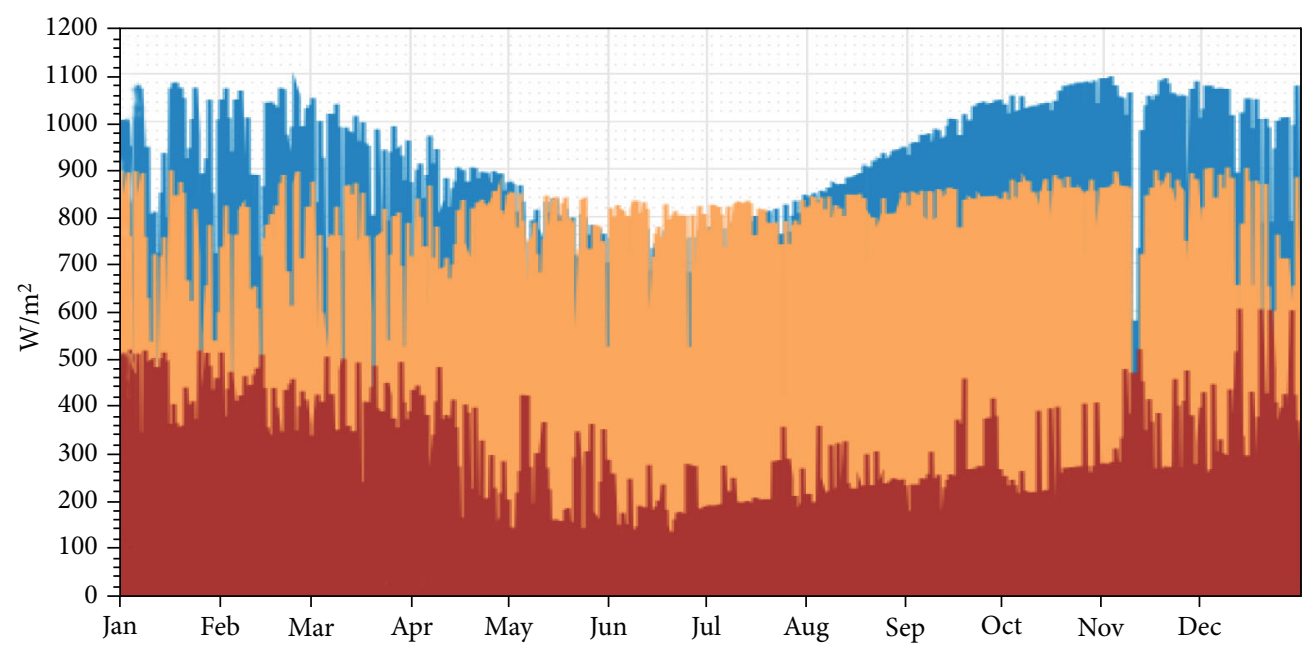

GHI calculated

DNI from weather file

DHI from weather file

FIGURE 2: Monthly solar irradiance in Zambia.

The main reason for this huge loss of $87.7 \%$ irradiance in the plane of array (POA) is attributed to factors like the position of the sun, the orientation of the array (fixed or tracking), how much diffused and direct irradiance is available to the PV module, the ground surface reflection (this characteristic is referred to as Albedo), and the amount of shading or obstructions near the installed PV system [40].

Figure 4(c) shows the annual PV module is far less efficient in the designed SAM PV model compared to the inverter. This shows that the system can be improved by replacing the PV module with a more efficient PV module to reduce losses and improve the system output. The efficiency of the selected Chinese PV module, Nanjing CSUN285-60M is $17.6875 \%$ while some commercially available PV modules are as high as $22.7 \%$, particularly the monocrystalline X-series module, SPR-X22-370 which is manufactured by SunPower. However, these highperformance PV modules come at a higher price [41].

Figure 5(a) shows several cash flow metrics that would help the researcher derive some conclusions on whether the solar PV project is a viable and feasible energy solution in Zambia. Out of all these matrices, the performance ratio and capacity factor and energy yield are important performance indicators. To help assess the financial viability, the IRR of $11.28 \%$ and a NPV of US $\$ 343$ results helped the researcher justify or refute its financial viability and feasibility. The designed solar PV project in Zambia yielded in Figure 5(a), a nominal LCOE of US $\$ 52.06 \mathrm{c} / \mathrm{kWh}$. The value is found to be suitable for analysis for the 5 years of project life in Zambia although much higher than the global average weight of US $\$ 8.5 \mathrm{c} / \mathrm{kWh}$ partly because the project design for Zambia is short-term (5 years), a high inflation rate of $10.7 \%$, and no discount rate and investment tax credit incentives are captured in SAM [25, 42, 43]. The significance of LCOE is to help solar PV designers to compare electricity generation technologies or optimize the solar PV system as it takes into account the amount of electricity generated by the PV system, the installation costs, and operation and maintenance costs for the project over its life [25]. Similarly, the PPA price value of $40 \mathrm{c} / \mathrm{kWh}$, the levelized PPA price (real) obtained $61.65 \mathrm{c} / \mathrm{kWh}$ price is also affected by the high cost of PV components, high-interest rate, and high inflation rate $(10.7 \%)$ in Zambia.

Further, a comparison of solar power and diesel generator energy source in Zambia would be a useful indicator for financial viability assessment; using equation (4) and calculating the LCOE using diesel for a $2 \mathrm{~kW}$ diesel generators costing US $\$ 300$ at a consumption rate of 0.76 liters per hour, the total fuel required to generate the required $30 \mathrm{kWh}$ is 22.8 liters per day and 461.79 liters of diesel will be required to produce $613 \mathrm{kWh}$ annually. The total electricity production, including losses, is $1073 \mathrm{kWh}$. Assuming that there are no FCR charges (unity) at a cost of US $\$ 1 / \mathrm{Lt}$, the LCOE diesel in Zambia is calculated to be US $\$ 1.29 / \mathrm{kWh}$ which is more expensive than the solar solution [44].

Figure 5(b) shows the project cash flow after tax. It clearly shows the total debt and how the energy produced in years 1 , 2 , and 3 offset even when the project life is projected to a period of 5 years.

In summary, the financial metrics all indicate that solar PV project for grid-connected homes in Zambia with a capacity factor of providing $12.3 \%$ of electricity throughout the year yields the $98.13 \%$ expected energy of $1093.47 \mathrm{kWh} / \mathrm{kW}$, thereby making the PV system, very good, 


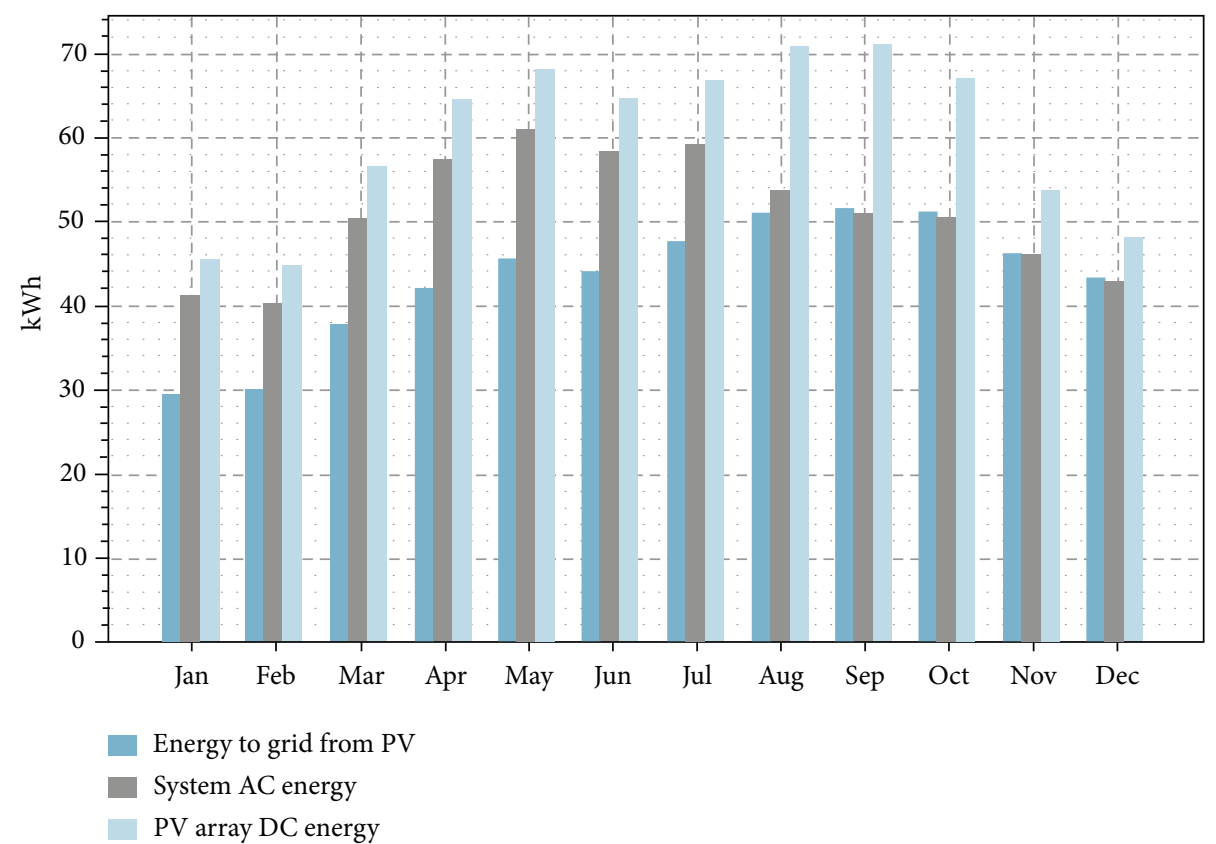

(a)

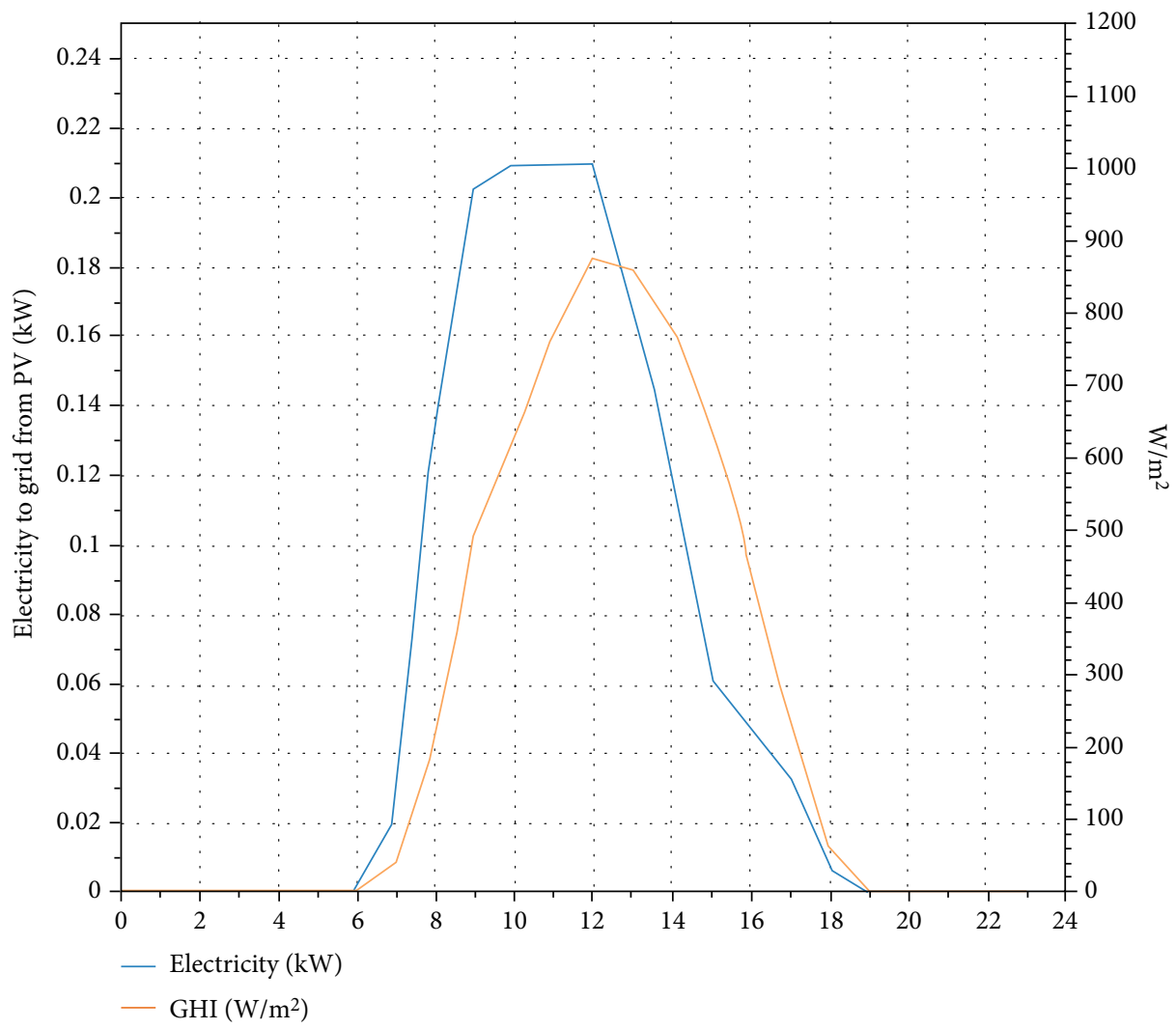

(b)

FIGURE 3: (a) Monthly energy production. (b) Average annual energy production vs. irradiance.

feasible, and viable system concerning performance with a rating of $69 \%$ [21]. Table 2 summarizes the financial metrics for the designed PV system.

Table 2 shows that the designed project is a short-term 5year project with an $11.28 \%$ internal rate of return met in the third year and thus financially not risky, economically feasible because, throughout the 5-year project life, the DSCR shows that the project is at least five times capable of offsetting its debt because it has adequate earnings before interest, taxes, depreciation, and amortization (EBITDA) and has 


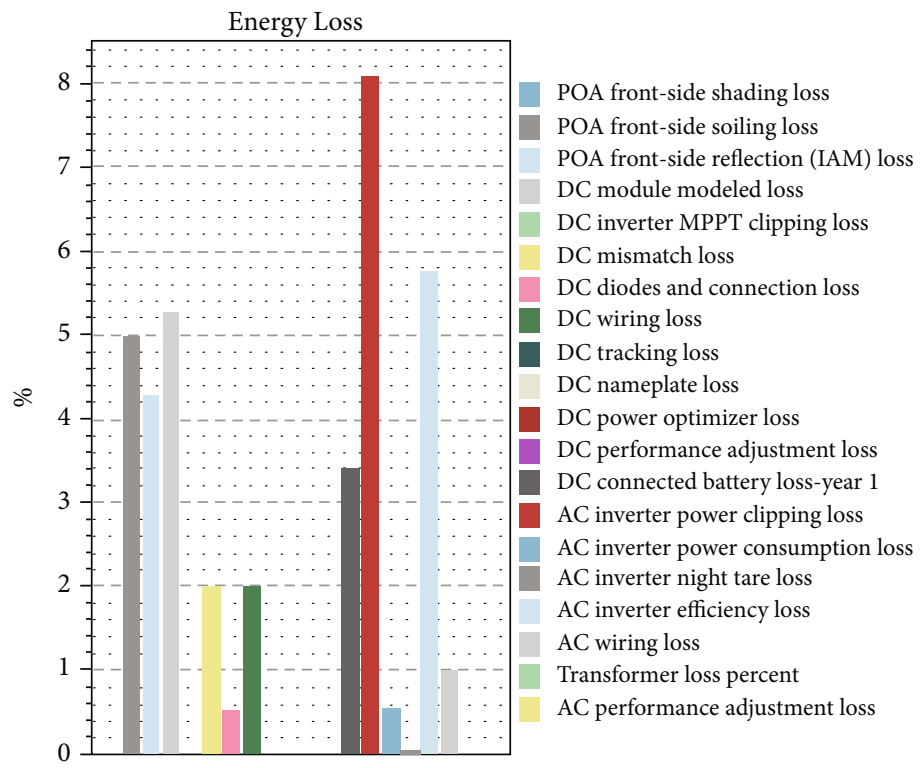

(a)

FIgURe 4: Continued. 

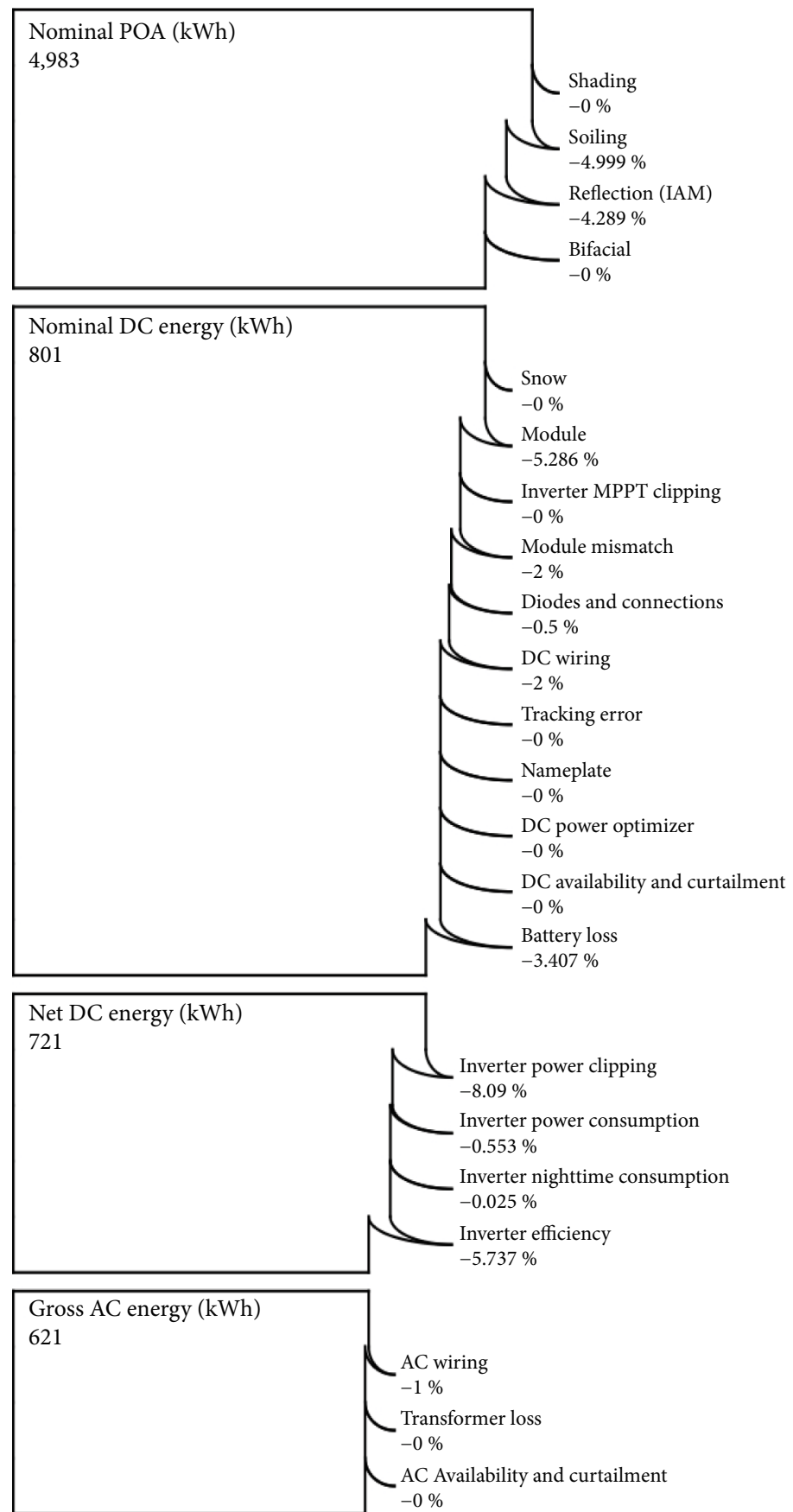

\begin{tabular}{l}
\hline $\begin{array}{l}\text { Annual energy (kWh) } \\
613\end{array}$ \\
\hline
\end{tabular}

(b)

Figure 4: Continued. 


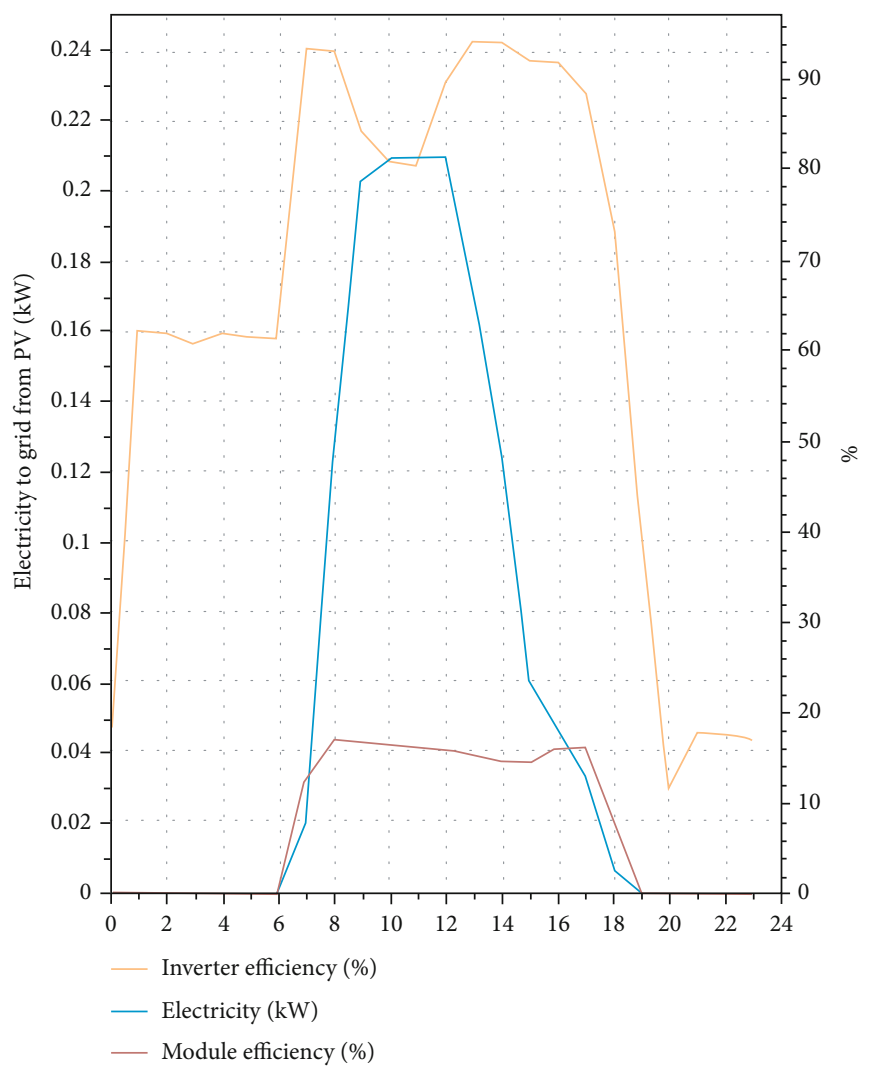

(c)

Figure 4: (a) System losses. (b) PV energy Sankey diagram. (c) Annual PV module and inverter efficiency.

\begin{tabular}{|lc|}
\hline Metric & Value \\
\hline Annual energy (year 1) & $613 \mathrm{kWh}$ \\
\hline Capacity factor (year 1) & $12.3 \%$ \\
\hline Energy yield (year 1) & $1,073 \mathrm{c} / \mathrm{kWh}$ \\
\hline Performance ratio (year 1) & 0.69 \\
\hline Battery efficiency (incl. converter + ancilary) & $88.19 \%$ \\
\hline PPA price (year 1) & $40.00 \mathrm{c} / \mathrm{kWh}$ \\
\hline PPA price escalation & $0.00 \% /$ year \\
\hline Levelized PPA price (nominal) & $82.56 \mathrm{c} / \mathrm{kWh}$ \\
\hline Levelized PPA price (real) & $61.65 \mathrm{c} / \mathrm{kWh}$ \\
\hline Levelized COE (nominal) & $69.72 \mathrm{c} / \mathrm{kWh}$ \\
\hline Levelized COE (real) & $52.06 \mathrm{c} / \mathrm{kWh}$ \\
\hline Net present value & $\$ 343$ \\
\hline Internal rate of return (IRR) & $11.28 \%$ \\
\hline Year IRR is achieved & 3 \\
\hline IRR at end of project & $28.52 \%$ \\
\hline Net capital cost & $\$ 733$ \\
\hline Equity & $\$ 733$ \\
\hline Size of debt & $\$ 0$ \\
\hline Minimum DSCR & 5.12 \\
\hline
\end{tabular}

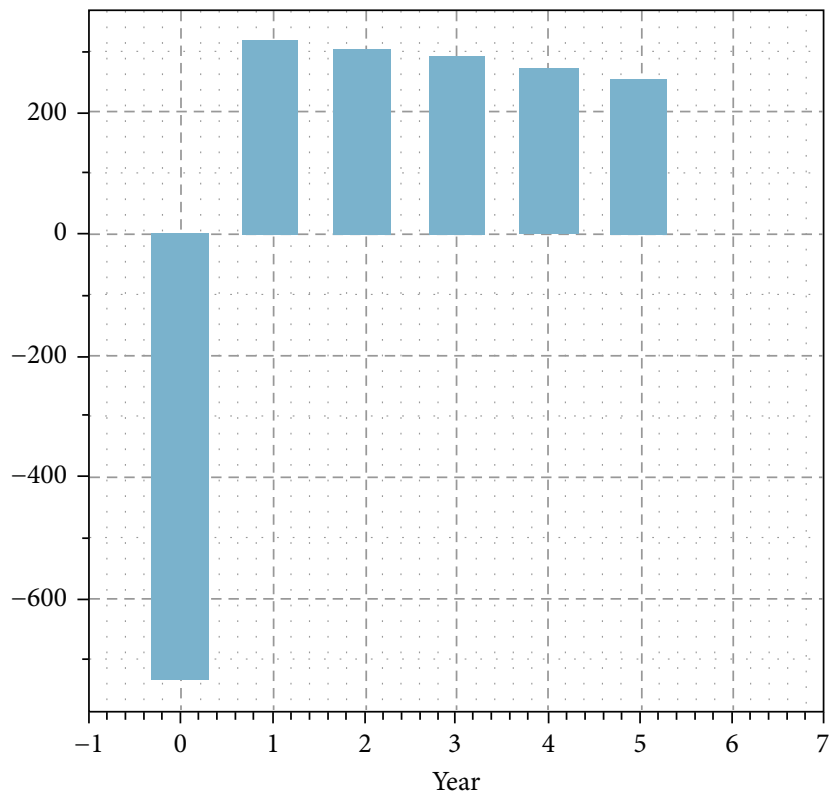

(a)

(b)

Figure 5: (a) Cash flow metric report. (b) Project after-tax cash flow. 
TABle 2: Financial model critical metric summary.

\begin{tabular}{lccccc}
\hline Year & $\begin{array}{c}\text { After-tax project cumulative IRR } \\
(\%)\end{array}$ & $\begin{array}{c}\text { After-tax project cumulative NPV } \\
(\$)\end{array}$ & $\begin{array}{c}\text { EBITDA } \\
(\$)\end{array}$ & $\begin{array}{c}\text { DSCR } \\
\text { (pretax) }\end{array}$ & $\begin{array}{c}\text { O\&M-annual battery } \\
\text { replacement }(\$)\end{array}$ \\
\hline 1 & NaN & -733.05 & 0 & 0 & 0 \\
2 & -57.2022 & -449.389 & 446.792 & 6.09497 & 144 \\
3 & -11.0528 & -203.396 & 431.528 & 5.88674 & 159.264 \\
4 & 11.2757 & 8.53838 & 414.646 & 5.65645 & 176.146 \\
5 & 22.4936 & 189.679 & 395.974 & 5.40174 & 194.817 \\
6 & 28.5203 & 342.978 & 375.324 & 5.12003 & 215.468 \\
\hline
\end{tabular}

NaN-IRR period is infinite and therefore not applicable to year 1 .

only the battery replacement expenses as major operations and maintenance costs to yield $613 \mathrm{~kW}$ annually.

\section{Conclusions and Recommendations}

The solar photovoltaic performance and financial modeling solution for grid-connected homes in Zambia is a feasible and viable solution that is capable of reducing the unacceptable and prolonged load shedding hours from the current 20 hours by less than half or completely gotten rid of to provide electricity to the poor majority and small business owners who depend on electricity and cannot afford diesel power as an alternative to hydropower because of the high LCOE diesel in Zambia of about US\$1.29/kWh compared to a solar option with a nominal LCOE US\$69.72 c/kWh. In the absence of economic issues in the Zambian economy, the real LCOE would be US $\$ 52.06 \mathrm{c} / \mathrm{kWh}$. This indicates that there is a need for the government to resolve this unfavorable business climate.

The financial metrics all indicate that solar PV project for grid-connected homes in Zambia with a capacity factor of providing $12.3 \%$ of electricity throughout the year yields the $98.13 \%$ expected energy of $1093.47 \mathrm{kWh} / \mathrm{kW}$, thereby making the PV system, very good, feasible, and viable system concerning performance with a rating of $69 \%$. The performance system of $69 \%$ shows that there is room for improvement to achieve high performance by first deploying high-performance PV modules, inverter, and storage battery. However, this performance upgrade would come at an extra cost. Second, the selection of lower performance PV modules and inverter was aimed at lowering the cost of the entire modeled PV system and depicting the products currently available on the Zambian market. The financial model shows that the solar PV project is financially feasible and viable because first, the project is five times capable of repaying the debt (DSCR, 5.12) and second, within three years (IRR, 11.28\%), although the current business climate is not so sustainable because of high inflation rates exceeding $10 \%$. Further, there is a need for the Zambian government to ensure that a conducive financial climate is restored in Zambia and give financial institutions the confidence to engage in long-term loans with its clients especially on development projects like solar energy development so that the solar PV loans should be serviced in about 15 years to 20 years. This would also increase the IRR and affordability of the loans by all in Zambia. This research is approached with facts from the prevailing business climate characterized with high inflation rates exceeding $10 \%$, high lending interest rates on loans of about $30 \%$, high value-added tax of $16 \%$, and no investment tax credit (ITC) of $30 \%$ as those applied in developed nations and leaders of solar installations like Germany and the USA. However, the few wealthy individuals in Zambia can take advantage of the zero percent $(0 \%)$ import duty on solar equipment in Zambia.

The significance and unusual nature of this research are that a 5-year short-term solar PV system, incorporating a PPA, is feasible and can still be modeled even if the business climate in Zambia is unsustainable, to resolve the current electrical power crisis characterized by prolonged load shedding hours from the current 20 hours. To enhance the power purchase agreement (PPA) between ZESCO and the people of Zambia and explore the opportunity for Zambia to transition from being a hydrodependent nation to a solar-dependent nation and supply affordable and cleaner energy for the poor majority in Zambia, six strategies that can be adopted are as follows: (1) the single households should enter PPA with ZESCO and the Zambian government to help single homeowners secure the loans to implement the project alongside providing ZESCO technicians to carry out the installations as a major incentive; (2) improve the PV system to be installed by using more efficient PV modules, better battery storage systems with higher capacity and DC harmonic filters so that the excess power can be supplied to the grid for other users; (3) take advantage of the abundant DNI and adopt more diverse types of solar systems especially concentrator PV systems $(\mathrm{CPV})$ and thermal solar power plants (CSP) which can be used for several applications like solar geysers, solar milk pasteurisation, and thermal electricity generation; (4) reduce carbon emission contributions by diesel generators that are used as alternative to the hydropower which is in shortsupply; (5) reduce the nominal LCOE of US $\$ 52.06 \mathrm{c} / \mathrm{kWh}$ for the 5-year short-term projects with project life in Zambia to as low as the global average weight of US $\$ 8.5 \mathrm{c} / \mathrm{kWh} \mathrm{LCOE}$ by modeling optimal solar systems over longer financing periods of 15 years to 25 years alongside providing conducive business climate concerning economic stability and sustainable lending financial terms by government, to reduce the current economic shocks; and (6) Zambia can share expertise with other nations in Africans, concerning solar engineering and help unlock Africa's solar potential. 
Nomenclature

$\begin{array}{ll}\text { Units } & \\ \text { Adc: } & \text { Direct-voltage current } \\ \text { c/kWh: } & \text { Cent per kilo-watt-hour } \\ \text { GW: } & \text { Gigga-watt } \\ \text { Isc: } & \text { Short-circuit current } \\ \text { Imp: } & \text { Current maximum power } \\ \text { kW: } & \text { Kilo-watt } \\ \text { kWh: } & \text { Kilo-watt-hour } \\ \text { kWh/km }{ }^{2} \text { : } & \text { Kilo-watt-hour per kilometer square } \\ \text { Pmp: } & \text { Maximum power } \\ \text { Vmp: } & \text { Voltage maximum power } \\ \text { Voc: } & \text { Open-circuit voltage } \\ \text { Vdc: } & \text { Direct-current voltage } \\ \text { V: } & \text { Voltage } \\ \text { Wac: } & \text { Maximum AC power } \\ \text { Wdc: } & \text { Maximum DC power } \\ \text { Vac: } & \text { Alternating-current voltage } \\ \text { W/m }{ }^{2}: & \text { Watt per square meter. }\end{array}$

\section{Abbreviations}

$\begin{array}{ll}\text { CPV: } & \text { Concentrator PV systems } \\ \text { CSP: } & \text { Solar power plants } \\ \text { DSCR: } & \text { Debt service coverage ratio } \\ \text { DNI: } & \text { Direct normal irradiance } \\ \text { DHI: } & \text { Diffuse horizontal irradiance } \\ \text { EBITDA: } & \text { Earnings before interest, taxes, depreciation and } \\ & \text { amortization } \\ \text { FCR: } & \text { Full cost recovery } \\ \text { GTI: } & \text { Global tilt irradiation } \\ \text { IRR: } & \text { Internal rate of return } \\ \text { LCOE: } & \text { Levelized cost of electricity } \\ \text { LC: } & \text { Inductance-capacitive } \\ \text { Lt: } & \text { Liter } \\ \text { MPPT: } & \text { Maximum power point tracking } \\ \text { m-Si: } & \text { Monosilicon } \\ \text { NPV: } & \text { Net present value } \\ \text { O\&M: } & \text { Operations and maintenance } \\ \text { PV: } & \text { Photovoltaic } \\ \text { POA: } & \text { Plane of array } \\ \text { PPA: } & \text { Power purchase agreement } \\ \text { p-Si: } & \text { Polysilicon } \\ \text { RLC: } & \text { Resistive-inductive-capacitive } \\ \text { TOU: } & \text { Time of use } \\ \text { SAM: } & \text { System advisor model } \\ \text { ZESCO: } & \text { Zambia Electricity Supply Corporation. } \\ & \end{array}$

\section{Data Availability}

This research is based on the NREL System Advisor Model (SAM) and current weather file database for Zambia from Climate.OneBuilding.

\section{Conflicts of Interest}

The author declares no conflicts of interest.

\section{Acknowledgments}

The author thanks Professor Valerie M. Thomas of Georgia Institute of Technology, USA, for her contributions to this work.

\section{References}

[1] ZESCO, Country Wide Load Shedding Schedule November 2019, 2019.

[2] M. Solano-Peralta, M. Moner-Girona, W. G. J. H. M. van Sark, and X. Vallvè, “"Tropicalisation” of feed-in tariffs: a custommade support scheme for hybrid PV/diesel systems in isolated regions," Renewable and Sustainable Energy Reviews, vol. 13, no. 9, pp. 2279-2294, 2009.

[3] T. Levin and V. M. Thomas, "Least-cost network evaluation of centralized and decentralized contributions to global electrification," Energy Policy, vol. 41, pp. 286-302, 2012.

[4] T. Arai and S. Wakao, "Computational analysis of battery operation in photovoltaic systems with varying charging and discharging rates," in 2016 IEEE 43rd Photovoltaic Specialists Conference (PVSC), pp. 1-6, Portland, OR, USA, 2016.

[5] M. H. Athari and Z. Wang, "Modeling the uncertainties in renewable generation and smart grid loads for the study of the grid vulnerability," in 2016 IEEE Power \& Energy Society Innovative Smart Grid Technologies Conference (ISGT), pp. 1-5, Minneapolis, MN, USA, 2016.

[6] A. Park and P. Lappas, "Evaluating demand charge reduction for commercial-scale solar PV coupled with battery storage," Renewable Energy, vol. 108, pp. 523-532, 2017.

[7] A. S. Mobarakeh, R.-G. Abbas, and Z. Aydin, "A game theoretic framework for DG optimal contract pricing," in IEEE PES ISGT Europe 2013, Lyngby, Denmark, 2014.

[8] T. Bano and K. Rao, "Performance analysis of $1 \mathrm{MW}$ grid connected photovoltaic power plant in Jaipur, India," in 2016 International Conference on Energy Efficient Technologies for Sustainability (ICEETS), pp. 1-6, Nagercoil, India, 2016.

[9] C. P. Cameron, W. E. Boyson, and D. M. Riley, "Comparison of PV system performance-model predictions with measured PV system performance," in 2016 International Conference on Energy Efficient Technologies for Sustainability (ICEETS), Nagercoil, India, 2009.

[10] S. Edalati, M. Ameri, and M. Iranmanesh, "Comparative performance investigation of mono- and poly-crystalline silicon photovoltaic modules for use in grid-connected photovoltaic systems in dry climates," Applied Energy, vol. 160, pp. 255265, 2015.

[11] F. U. H. Faiz, R. Shakoor, A. Raheem, F. Umer, N. Rasheed, and M. Farhan, "Modeling and Analysis of 3 MW Solar Photovoltaic Plant Using PVSyst at Islamia University of Bahawalpur, Pakistan," International Journal of Photoenergy, vol. 2021, Article ID 6673448, 14 pages, 2021.

[12] M. Benchrifa, R. Tadili, A. Idrissi, H. Essalhi, and A. Mechaqrane, "Development of New Models for the Estimation of Hourly Components of Solar Radiation: Tests, Comparisons, and Application for the Generation of a Solar Database in Morocco," International Journal of Photoenergy, vol. 2021, Article ID 8897818, 16 pages, 2021.

[13] A. Gopi, K. Sudhakar, N. W. Keng, A. R. Krishnan, and S. S. Priya, "Performance modeling of the weather impact on a utility-scale PV power plant in a tropical region," International 
Journal of Photoenergy, vol. 2021, Article ID 5551014, 10 pages, 2021.

[14] K. Padmavathi and S. A. Daniel, "Performance analysis of a 3 $\mathrm{MW}_{\mathrm{p}}$ grid connected solar photovoltaic power plant in India," Energy for Sustainable Development, vol. 17, no. 6, pp. 615625, 2013.

[15] K. Attari, A. Elyaakoubi, and A. Asselman, "Performance analysis and investigation of a grid-connected photovoltaic installation in Morocco," Energy Reports, vol. 2, pp. 261-266, 2016.

[16] A. K. Shukla, K. Sudhakar, and P. Baredar, "Simulation and performance analysis of $110 \mathrm{~kW}_{\mathrm{p}}$ grid- connected photovoltaic system for residential building in India: A comparative analysis of various PV technology," Energy Reports, vol. 2, pp. 82$88,2016$.

[17] H. Moradi, A. Abtahi, and A. Zilouchian, "Financial analysis of a grid-connected photovoltaic system in South Florida," in 2017 IEEE 44th Photovoltaic Specialist Conference (PVSC), pp. 1-6, 2017.

[18] Energy Plus Weather, ““Climate.OneBuilding.Org”, Repository of free climate data for building performance simulation," 2019, http://climate.onebuilding.org/default.html.

[19] Solar Africa Shop, "Solar Africa Shop," 2019, https://www .solar-africa-shop.com/solar-inverters/solar-inverters-africa.

[20] S. Nalishebo, "Who are the middle class in Zambia?," 2013, https://www.africaportal.org/publications/who-are-themiddle-class-in-zambia/.

[21] NREL, “System Advisor Model Help," 2018, https://sam.nrel.gov.

[22] AB Bank, "Micro business loans," 2020, https://www.abbank .co.zm/business-loans/.

[23] FINCA, "General Financial Assistance and Products," 2020, https://www.finca.co.zm/loans/.

[24] Helio Power, "Solar Project Finance Map," 2020, https:// heliopower.com/energy-finance-services/solar-projectfinance/.

[25] K. Branker, M. J. M. Pathak, and J. M. Pearce, "A review of solar photovoltaic levelized cost of electricity," Renewable and Sustainable Energy Reviews, vol. 15, no. 9, pp. 44704482, 2011.

[26] Y. Matsumoto, J. A. Urbano, O. I. Gomez, R. Asomoza, J. Garcia, and R. Pena, "Seasonal quality factor; $60 \mathrm{kWp} \mathrm{PV}$ system at north Mexico City," in 2014 IEEE 40th Photovoltaic Specialist Conference (PVSC), Denver, CO, USA, 2014.

[27] J. Doyle, "What is the optimal DC/AC inverter ratio for commercial solar power systems?," 2018, https://solarbay.com.au/ optimal-dc-ac-inverter-ratio-commercial-solar-powersystems/.

[28] "Satlex calculator," 2019, https://satlex.de/en/azel_calcparams.html? satlo $=46.0$ \&user_satlo $=\&$ user_satlo_dir $=$ W \&location $=-15.41 \% 2 \mathrm{C} 28.28 \& \mathrm{la}=-15.41 \& \mathrm{lo}=28$ $.28 \&$ country_code $=$ zm\&diam_w $=75 \&$ diam_h $=80$.

[29] ZESCO, "Comparison of electricity pricing in the southern African region," 2019 , http://www.zesco.co.zm/ customerCare/tariffs.

[30] SEIA, "Solar investment tax credit," 2019, https://www.seia .org/initiatives/solar-investment-tax-credit-itc.

[31] K. Imasiku and E. Ntagwirumugara, "An impact analysis of population growth on energy-water-food-land nexus for ecological sustainable development in Rwanda," Food and Energy Security, vol. 9, no. 1, 2020.
[32] K. Imasiku, V. Thomas, and E. Ntagrirumugara, "Unraveling green information technology systems as a global greenhouse gas emission game-changer," Administrative Sciences, vol. 9, no. 43, pp. 1-29, 2019.

[33] GeoModel Solar, "Solar resource mapping in Zambia," 2014, https://solargis.com/maps-and-gis-data/download/zambia.

[34] N. Hagumimana, J. Zheng, G. N. O. Asemota et al., "Concentrated Solar Power and Photovoltaic Systems: A New Approach to Boost Sustainable Energy for All (Se4all) in Rwanda," International Journal of Photoenergy, vol. 2021, Article ID 5515513, 32 pages, 2021.

[35] D. Wetterdienst, "Satellite-based retrieval of surface solar radiation," 2019, https://www.dwd.de/EN/ourservices/ solarenergy/satellite_solarradiation.html;jsessionid= 0C3F458F8C3F3AF3B6C23184D059EA7F.live11054?nn= 495490\&lsbId $=570780$.

[36] H. Wirth, "Recent facts about photovoltaics in Germany," 2019, https:/www.ise.fraunhofer.de/content/dam/ise/en/ documents/publications/studies/recent-facts-aboutphotovoltaics-in-germany.pdf.

[37] Energy Regulation Board, “Statistical bulletin 2018," 2018, https://www.erb.org.zm/downloads/eregulation/ statisticalbulletin/statBullet2018.pdf.

[38] Renewable Energy World, "Solar PV system efficiency and rain,” 2016, https://www.renewableenergyworld.com/2016/ 07/08/solar-panel-efficiency-in-the-rain/\#gref.

[39] S. Ghazi and K. Ip, "The effect of weather conditions on the efficiency of PV panels in the southeast of UK," Renewable Energy, vol. 69, pp. 50-59, 2014.

[40] PV Performance - Modelling Collaborative, "Plane of array irradiance,” 2019, https://pvpmc.sandia.gov/modeling-steps/ 1-weather-design-inputs/shading-soiling-and-reflectionlosses/incident-angle-reflection-losses/.

[41] ecotality, “The 20 most efficient solar panels of 2019," 2019, https://ecotality.com/most-efficient-solar-panels/\#The-MostEfficient-Solar-Panels-of-2019-The-Top-5.

[42] IRENA, “Renewable power generation costs in 2018," 2019, https://www.irena.org/-/media/Files/IRENA/Agency/ Publication/2019/May/IRENA_Renewable-PowerGenerations-Costs-in-2018.pdf.

[43] IRENA, "Solar PV in Africa: costs and markets," 2016, https:// www.irena.org/publications/2016/Sep/Solar-PV-in-AfricaCosts-and-Markets.

[44] T. Levin and V. M. Thomas, "Utility-maximizing financial contracts for distributed rural electrification," Energy, vol. 69, pp. 613-621, 2014. 